\title{
Activating TYK2 Gene Mutation
}

National Cancer Institute

\section{Source}

National Cancer Institute. Activating TYK2 Gene Mutation. NCI Thesaurus. Code

C157596.

A change in the nucleotide sequence of the TYK2 gene that that results in constitutive activation of both non-receptor tyrosine-protein kinase TYK2 protein and its downstream signaling pathways. 